\title{
SURFACE COMPLEXATION MODELING IN VARIABLE CHARGE SOILS: PREDICTION OF CADMIUM ADSORPTION
}

\author{
Giuliano Marchi ${ }^{(1)^{*}}$, Cesar Crispim Vilar ${ }^{(2)}$, George O'Connor ${ }^{(3)}$, Letuzia Maria de Oliveira ${ }^{(3)}$, \\ Adriana Reatto ${ }^{(1)}$ and Thomaz Adolph Rein ${ }^{(1)}$
}

(1) Empresa Brasileira de Pesquisa Agropecuária, Embrapa Cerrados, Brasília, Distrito Federal, Brasil.

(2) Universidade do Estado de Mato Grosso, Campus Nova Xavantina, Nova Xavantina, Mato Grosso, Brasil.

(3) University of Florida, Soil and Water Sciences Department, Gainesville, Florida, United States.

* Corresponding author.

E-mail: giuliano.marchi@embrapa.br

\begin{abstract}
Intrinsic equilibrium constants for 22 representative Brazilian Oxisols were estimated from a cadmium adsorption experiment. Equilibrium constants were fitted to two surface complexation models: diffuse layer and constant capacitance. Intrinsic equilibrium constants were optimized by FITEQL and by hand calculation using Visual MINTEQ in sweep mode, and Excel spreadsheets. Data from both models were incorporated into Visual MINTEQ. Constants estimated by FITEQL and incorporated in Visual MINTEQ software failed to predict observed data accurately. However, FITEQL raw output data rendered good results when predicted values were directly compared with observed values, instead of incorporating the estimated constants into Visual MINTEQ. Intrinsic equilibrium constants optimized by hand calculation and incorporated in Visual MINTEQ reliably predicted Cd adsorption reactions on soil surfaces under changing environmental conditions.
\end{abstract}

Keywords: intrinsic equilibrium constants, Oxisol, FITEQL, Visual MINTEQ, chemical equilibrium software.

\footnotetext{
RESUMO: MODELAGEM POR COMPLEXAÇÃO DE SUPERFÍCIE EM SOLOS DE CARGA VARIÁVEL: PREDIÇÃO DA ADSORÇÃO DE CÁDMIO

Constantes de equilíbrio intrínsecas de 22 Latossolos brasileiros representativos da região do Cerrado foram estimadas por meio de um experimento de adsorção de cádmio. As constantes de equilíbrio foram ajustadas a dois modelos de superfície de complexação: camada difusa e capacitância constante. As constantes
} 
de equilíbrio intrínsecas foram otimizadas pelo programa FITEQL e pelo cálculo manual usando o programa Visual MINTEQ no modo "sweep" e planilhas do Excel. Dados dos dois modelos foram incorporados ao Visual MINTEQ. As constantes estimadas pelo FITEQL e incorporadas ao Visual MINTEQ falharam ao predizer acuradamente os dados observados. Entretanto, os dados brutos de saida do FITEQL geraram bons resultados quando os valores preditos foram comparados diretamente aos observados, em vez de incorporar as constantes estimadas ao Visual MINTEQ. A predição das reações de adsorção de Cd na superfície do solo pelas constantes de equilíbrio intrínsecas otimizadas pelos cálculos manuais e incorporadas ao Visual MINTEQ foram confiáveis e podem ser utilizadas sob diversas situações ambientais.

\section{Palavras-chave: constantes de equilíbrio intrínsecas, Latossolos, FITEQL, Visual MINTEQ, programa de equilibrio químico.}

\section{INTRODUCTION}

Anthropogenic activities, such as mining or industrial activities, agricultural chemical applications - mainly phosphate and zinc micronutrients (Guilherme et al., 2014), and organic and inorganic residue application to soils may cause cadmium $(\mathrm{Cd})$ concentration to build up over time. Cadmium is bound to the solid phase of soils as a result of surface precipitation and adsorption processes. Its mobility and destination in the soil environment are directly related to processes that are highly $\mathrm{pH}$ dependent (Lee et al., 1996).

Soil contamination by $\mathrm{Cd}$ is of great concern in terms of its entry into the food chain for it can be taken up by food plants in large amounts relative to its concentration in the soil. Furthermore, Cd accumulates over a lifetime in the body (ATSDR, 2012) and has adverse health effects, mainly in the form of renal dysfunction (Hooda, 2010). Environmental and human health risk assessment of metals depends to a great extent on modeling the destination and mobility of metals based on soil-liquid partitioning coefficients (Sauvé et al., 2000) that can be estimated locally.

Cadmium adsorption is mainly controlled by soil organic matter (Lee et al., 1996; Shi et al., 2007), pH (Sauvé et al., 2000), cation exchange capacity, clay content or type, surface area (Appel and Ma, 2002), surface charge (He et al., 2005), or a combination of those soil components. Different components in soils may contribute to $\mathrm{Cd}$ adsorption to different extents (Shi et al., 2007). Indeed, controlling the factors of $\mathrm{Cd}$ adsorption in highly weathered soils, such as Oxisols, are not clear (Alleoni and Camargo, 1994). Correlation coefficients between $\mathrm{Cd}$ adsorption and many soil properties for 17 Oxisols were inconclusive at $\mathrm{pH} 4.5$, but highly significant at $\mathrm{pH}$ values of 5.5 and 6.5. Properties such as surface area, CEC, clay, kaolinite, and hematite contents were highly correlated (Pierangeli et al., 2003), emphasizing the importance of $\mathrm{pH}$, surface area, and charge for $\mathrm{Cd}$ adsorption in these soils. Understanding mechanisms of metal adsorption in soils is important as these reactions control the strength of the metal-soil surface interactions (He et al., 2005).

Oxisols are characterized by B horizons with 1:1 clay minerals and variable amounts of $\mathrm{Fe}$ and Al hydrous oxides (Reatto et al., 2009a), exhibiting generally low surface charge density with predominant $\mathrm{pH}$-dependent surface charge. Charge develops from protonation and deprotonation reactions of hydroxyl groups protruding from the surfaces of the minerals, and by deprotonation of acidic functional groups exposed on the surfaces of solid organic matter (Charlet and Sposito, 1987).

Little research has been done directly comparing surface charge with heavy metal sorption in variable charge systems (Appel and $\mathrm{Ma}, 2002$ ). In this regard, surface complexation models have distinct advantages over empirical models (which provide soil-liquid partitioning coefficients for further modeling) because surface complexation models can be extrapolated to systems of different ionic strengths, pH's, and component compositions (Koretsky, 2000; Bethke, 2008). However, application of the surface complexation modeling approach to natural systems, such as soils, is considerably more difficult, and rare, than application to simple mineral-water systems (Davis and Kent, 1990; Davis, 2001). Theory needs to describe hydrolysis and the mineral surfaces, account for electrical charge, and provide for mass balance on the sorbing sites. In addition, an internally consistent and sufficiently broad database of sorption reactions should accompany the theory (Bethke, 2008). Estimated intrinsic equilibrium constants must ultimately describe reliable results within chemical speciation software packages, such as Visual MINTEQ (Gustafsson, 2014), allowing end users to perform predictions and apply results in further technologies.

Intrinsic equilibrium constants estimated from $\mathrm{Cd}$ adsorption in soils, optimized by FITEQL and by hand calculation may be incorporated into Visual MINTEQ. Results may be validated as comparing observed results of Cd adsorption in four Oxisols with those predicted by Visual MINTEQ.

The overall objectives of this study were to estimate intrinsic equilibrium constants of $\mathrm{Cd}$ 
adsorption for 22 Oxisols, incorporate them into chemical speciation software, such as Visual MINTEQ, and validate the results, comparing observed results of $\mathrm{Cd}$ adsorption in four Oxisols with those predicted by Visual MINTEQ software.

\section{MATERIAL AND METHODS}

\section{Soil samples and properties}

Soil samples from the 0.00-0.20 m depth from 20 sites were collected and characterized for mineralogy, texture, organic carbon, and cation exchange capacity at pH 7.0 by Rein (2008); additional soils from horizons $\mathrm{A}$ and $\mathrm{Bw}$ from three sites were collected and characterized by Reatto et al. (2007, 2008, 2009a,b). The characterization data, displayed in tables 1 and 2, were used in the present study. Site location was based on survey reports to provide a representative sample of pristine Cerrado (tropical savanna) Oxisols from Brazil. Consideration was given to geographic distribution, variations in texture, mineralogical composition of the clay fraction, and parent material. All sampled sites were under native vegetation, and had never been cropped or amended.

Determination of surface area was performed as described by Cerato and Lutenegger (2002), with modifications. Soil was passed through a $2 \mathrm{~mm}$ sieve, oven dried for $12 \mathrm{~h}$ at $120^{\circ} \mathrm{C}$ to remove water, and then placed $(1 \mathrm{~g})$ in an aluminum tare. Three $\mathrm{mL}$ of ethylene glycol monoethyl ether (EGME) were mixed with the soil. Tares were placed in a desiccator and a $635 \mathrm{~mm} \mathrm{Hg}$ vacuum was applied. One hundred and 10 grams of oven-dried $\mathrm{CaCl}_{2}$ was used as a desiccant. After 18 and $24 \mathrm{~h}$, the desiccator was opened and the tares were weighed. If the mass of the sample varied more than $0.001 \mathrm{~g}$ from the first time to the second, the sample was placed once more in the desiccator and evacuated again for $4 \mathrm{~h}$ more. The procedure was repeated successively until the tares reached constant weight. Soil surface area $(A)$ was calculated as $A=\frac{W a}{2.86 \times 10^{-4} W s}$, where Wa is

the weight of EGME retained by the sample in $\mathrm{g}$; Ws is the oven dry weight of soil; and 0.000286 is the weight of EGME required to form a monomolecular layer on a square meter of surface $\left(\mathrm{m}^{2} \mathrm{~g}^{-1}\right)$. Reference clays from the Source Clay Mineral Repository at the University of Missouri at Columbia, Missouri, USA, were used to validate the method.

\section{Adsoption isotherms}

Cadmium adsorption envelopes (amount of $\mathrm{Cd}$ adsorbed as a function of solution $\mathrm{pH}$ at a fixed total $\mathrm{Cd}$ concentration) were determined for all soil samples. One g of soil was placed in polypropylene centrifuge tubes and brought to equilibrium with $15 \mathrm{~mL}$ of a $0.1 \mathrm{~mol} \mathrm{~L}^{-1} \mathrm{NaCl}$. Tubes were agitated at $200 \mathrm{rpm}$ for $12 \mathrm{~h}$ in a reciprocating shaker. Acid or base were added, and the operation was repeated several times, up to $72 \mathrm{~h}$ total time, to adjust initial suspension $\mathrm{pH}$ values to $4.5,5.0,5.5,6.0$, and 6.5. Each treatment had three replications. Five $\mathrm{mL}$ of $0.36 \mathrm{mmol} \mathrm{L}^{-1} \mathrm{Cd}$ solution in $0.1 \mathrm{~mol} \mathrm{~L}^{-1} \mathrm{NaCl}$ was mixed with the soil suspensions. Final Cd concentration in the soil suspension was $0.09 \mathrm{mmol} \mathrm{L}^{-1}$. Soil suspensions were shaken at $200 \mathrm{rpm}$ for $24 \mathrm{~h}$, and the $\mathrm{pH}$ of suspensions at the end of this procedure was recorded. Soil suspensions were centrifuged at $8000 \mathrm{rpm}$ for $10 \mathrm{~min}$, and the supernatant was collected for $\mathrm{Cd}$ analysis by inductive coupled plasma with mass spectrometry (ICP-MS).

A review of the theory and assumptions of the constant capacitance model, as well as of the diffuse layer model was presented in Goldberg (1992). The soil will be considered as an integrated whole with an average surface functional group (expressed as $\mathrm{SOH})$. The surface protonation and deprotonation of the soil are expressed as equations 1 and 2:

$$
\begin{array}{ll}
\mathrm{SOH}_{2}^{+}=\mathrm{SOH}+\mathrm{H}^{+} & \text {Eq. } 1 \\
\mathrm{SOH}=\mathrm{SO}^{-}+\mathrm{H}^{+} & \text {Eq. } 2
\end{array}
$$

The adsorption of $\mathrm{Cd}$ on the soil surface is expressed by the following surface complexation reaction (Equation 3).

$\mathrm{SOH}+\mathrm{Cd}^{2+}=\mathrm{SOCd}^{+}+\mathrm{H}^{+}$

Other reactions with $\mathrm{Cd}$ and $\mathrm{Cl}^{-}$were also included in the modeling, e.g., $\mathrm{CdCl}^{+}$and $\mathrm{CdCl}_{2}$ species played an important role in solution equilibria (equations summarized in table 3), even though $\mathrm{CdCl}^{+}$was not considered as a surface-bound species.

Intrinsic equilibrium constant expressions for the surface complexation reactions are:

$$
\begin{aligned}
K a_{+}^{\text {int }}=\frac{\left[S O H_{2}^{+}\right]}{[S O H]\left[H^{+}\right]} \exp \left[\frac{F \Psi}{R T}\right] & \text { Eq. } 4 \\
K a_{-}^{\text {int }}=\frac{\left[S O^{-}\right]\left[H^{+}\right]}{[S O H]} \exp \left[\frac{-F \Psi}{R T}\right] & \text { Eq. } 5 \\
K_{S O C d}^{\text {int }}=\frac{\left[S O C d^{+}\right]\left[H^{+}\right]}{[S O H]\left[\mathrm{Cd}^{2+}\right]} & \text { Eq. } 6
\end{aligned}
$$

where $\exp ( \pm \mathrm{F} \Psi / \mathrm{RT})$ is derived from the Boltzmann equation and used to adjust for the electrostatic properties of the charged surfaces; $\mathrm{F}$ is the Faraday constant $\left(\mathrm{C} \mathrm{mol}_{\mathrm{c}}^{-1}\right)$; $\Psi$ is the surface potential (V); $\mathrm{R}$ is the molar gas constant $\left(\mathrm{J} \mathrm{mol}^{-1} \mathrm{~K}^{-1}\right)$; $\mathrm{T}$ is the absolute temperature $(\mathrm{K})$; and square brackets indicate concentrations $\left(\mathrm{mol} \mathrm{L}^{-1}\right)$. 
Table 1. Selected soil mineralogical and chemical properties

\begin{tabular}{|c|c|c|c|c|c|c|c|c|c|c|c|}
\hline \multirow{2}{*}{ Soil } & \multirow{2}{*}{ Municipality, State } & \multirow{2}{*}{ Coordinate } & \multicolumn{5}{|c|}{ Mineralogical $^{(3)}$} & \multicolumn{3}{|c|}{$\mathrm{H}_{2} \mathrm{SO}_{4} / \mathrm{NaOH}$ method $^{(4)}$} & \multirow{2}{*}{$\mathbf{T}$} \\
\hline & & & $\mathbf{C t}$ & Gb & Gt & $\mathbf{H m}$ & An & $\mathrm{Si}$ & Al & $\mathbf{F e}$ & \\
\hline & & & \multicolumn{8}{|c|}{$\mathrm{g} \mathrm{kg}^{-1}$} & $\mathrm{mmol}_{\mathrm{c}} \mathrm{kg}^{-1}$ \\
\hline $1^{(1)}$ & Sete Lagoas, MG & $\mathrm{S} 19^{\circ} 27^{\prime} 18^{\prime \prime} \mathrm{W} 44^{\circ} 11^{\prime} 01^{\prime \prime}$ & 691 & 141 & 75 & 69 & 16 & 134 & 200 & 88 & 136.4 \\
\hline 2 & São Gotardo, MG & S $19^{\circ} 16^{\prime} 50^{\prime \prime} \mathrm{W} 46^{\circ} 09^{\prime} 13^{\prime \prime}$ & 108 & 571 & 206 & 34 & 57 & 23 & 241 & 133 & 101.9 \\
\hline 3 & Uberaba, MG & $\mathrm{S} 19^{\circ} 42^{\prime} 13^{\prime \prime} \mathrm{W} 47^{\circ} 57^{\prime} 35^{\prime \prime}$ & 228 & 262 & 193 & 179 & 107 & 45 & 151 & 205 & 38.9 \\
\hline 4 & Itumbiara, GO & $\mathrm{S} 18^{\circ} 17^{\prime} 07^{\prime \prime} \mathrm{W} 49^{\circ} 14^{\prime} 21^{\prime \prime}$ & 173 & 399 & 242 & 109 & 56 & 35 & 198 & 197 & 90.8 \\
\hline 5 & Balsas, MA & $\mathrm{S} 07^{\circ} 27^{\prime} 41^{\prime \prime} \mathrm{W} 46^{\circ} 01^{\prime} 04^{\prime \prime}$ & 921 & 0 & 91 & 0 & 17 & 164 & 184 & 48 & 20.9 \\
\hline 6 & Balsas, MA & $\mathrm{S} 08^{\circ} 30^{\prime} 55^{\prime \prime} \mathrm{W} 46^{\circ} 44^{\prime} 55^{\prime \prime}$ & 665 & 196 & 95 & 42 & 17 & 128 & 211 & 77 & 66.9 \\
\hline 7 & Correntina, BA & $\mathrm{S} 13^{\circ} 47^{\prime} 36^{\prime \prime} \mathrm{W} 45^{\circ} 52^{\prime} 56^{\prime \prime}$ & 865 & 15 & 83 & 13 & 25 & 151 & 180 & 51 & 19.3 \\
\hline 8 & Buritis, MG & S $15^{\circ} 21^{\prime} 24^{\prime \prime} \mathrm{W} 46^{\circ} 41^{\prime} 38^{\prime \prime}$ & 603 & 324 & 57 & 0 & 28 & 110 & 240 & 31 & 40.6 \\
\hline 9 & Planaltina, DF & $\mathrm{S} 15^{\circ} 36^{\prime} 53^{\prime \prime} \mathrm{W} 47^{\circ} 45^{\prime} 02^{\prime \prime}$ & 355 & 507 & 112 & 0 & 23 & 69 & 261 & 60 & 75.5 \\
\hline 10 & Planaltina, DF & $\mathrm{S} 15^{\circ} 35^{\prime} 55^{\prime \prime} \mathrm{W} 47^{\circ} 42^{\prime} 28^{\prime \prime}$ & 634 & 195 & 61 & 108 & 17 & 112 & 208 & 106 & 79.2 \\
\hline 11 & Planaltina, DF & S $15^{\circ} 36^{\prime} 36^{\prime \prime}$ W $47^{\circ} 44^{\prime} 14^{\prime \prime}$ & 259 & 529 & 185 & 0 & 19 & 44 & 240 & 93 & 44.7 \\
\hline 12 & Campo Grande, MS & $\mathrm{S} 20^{\circ} 25^{\prime} 03^{\prime \prime} \mathrm{W} 54^{\circ} 42^{\prime} 01^{\prime \prime}$ & 511 & 139 & 165 & 152 & 33 & 95 & 170 & 185 & 89.3 \\
\hline 13 & Campo Grande, MS & $\mathrm{S} 20^{\circ} 25^{\prime} 40^{\prime \prime} \mathrm{W} 54^{\circ} 43^{\prime} 28^{\prime \prime}$ & 623 & 102 & 88 & 156 & 25 & 117 & 176 & 152 & 99.6 \\
\hline 14 & Itiquira, MT & $\mathrm{S} 17^{\circ} 26^{\prime} 41^{\prime \prime} \mathrm{W} 54^{\circ} 15^{\prime} 51^{\prime \prime}$ & 776 & 41 & 58 & 103 & 19 & 138 & 175 & 99 & 45.7 \\
\hline 15 & Porto Nacional, TO & $\mathrm{S} 10^{\circ} 31^{\prime} 35^{\prime \prime} \mathrm{W} 48^{\circ} 20^{\prime} 30^{\prime \prime}$ & 425 & 403 & 149 & 0 & 23 & 76 & 236 & 78 & 46.5 \\
\hline 16 & Porto Nacional, TO & S $10^{\circ} 56^{\prime} 19^{\prime \prime} \mathrm{W} 48^{\circ} 18^{\prime} 07^{\prime \prime}$ & 630 & 251 & 60 & 55 & 17 & 113 & 215 & 69 & 26.5 \\
\hline 17 & Uruçuí, PI & $\mathrm{S} 07^{\circ} 28^{\prime} 07^{\prime \prime} \mathrm{W} 44^{\circ} 16^{\prime} 32^{\prime \prime}$ & 839 & 1 & 150 & 0 & 23 & 154 & 177 & 75 & 64.8 \\
\hline 18 & Panamá, GO & $\mathrm{S} 18^{\circ} 11^{\prime} 46^{\prime \prime} \mathrm{W} 49^{\circ} 17^{\prime} 00^{\prime \prime}$ & 430 & 222 & 107 & 189 & 30 & 82 & 180 & 181 & 153.7 \\
\hline 19 & Canarana, MT & $\mathrm{S} 13^{\circ} 31^{\prime} 29^{\prime \prime} \mathrm{W} 52^{\circ} 19^{\prime} 02^{\prime \prime}$ & 250 & 522 & 68 & 121 & 21 & 46 & 240 & 119 & 71.8 \\
\hline 20 & Sapezal, MT & $\mathrm{S} 13^{\circ} 32^{\prime} 23^{\prime \prime} \mathrm{W} 58^{\circ} 29^{\prime} 58^{\prime \prime}$ & 504 & 309 & 84 & 78 & 19 & 93 & 222 & 99 & 95.6 \\
\hline $21 \mathrm{~A}^{(2)}$ & Brasília, DF & $\mathrm{S} 15^{\circ} 36^{\prime} 92^{\prime \prime} \mathrm{W} 47^{\circ} 45^{\prime} 78^{\prime \prime}$ & 355 & 514 & 131 & 0 & - & 212 & 610 & 151 & 59.5 \\
\hline $21 \mathrm{~B}$ & Brasília, DF & $\mathrm{S} 15^{\circ} 36^{\prime} 92^{\prime \prime} \mathrm{W} 47^{\circ} 45^{\prime} 78^{\prime \prime}$ & 412 & 442 & 146 & 0 & - & 239 & 564 & 163 & 17.5 \\
\hline $22 \mathrm{~A}$ & Brasília, DF & $\mathrm{S} 15^{\circ} 13^{\prime} 24^{\prime \prime} \mathrm{W} 47^{\circ} 42^{\prime} 15^{\prime \prime}$ & 561 & 273 & 112 & 54 & - & 315 & 482 & 187 & 108.1 \\
\hline $22 \mathrm{~B}$ & Brasília, DF & $\mathrm{S} 15^{\circ} 13^{\prime} 24^{\prime \prime} \mathrm{W} 47^{\circ} 42^{\prime} 15^{\prime \prime}$ & 591 & 241 & 93 & 75 & - & 327 & 465 & 188 & 30.6 \\
\hline $23 \mathrm{~A}$ & Brasília, DF & S $15^{\circ} 14^{\prime} 08^{\prime \prime} \mathrm{W} 47^{\circ} 46^{\prime} 37^{\prime \prime}$ & 474 & 326 & 55 & 145 & - & 265 & 481 & 233 & 169.3 \\
\hline $23 \mathrm{~B}$ & Brasília, DF & S $15^{\circ} 14^{\prime} 08^{\prime \prime}$ W $47^{\circ} 46^{\prime} 37^{\prime \prime}$ & 399 & 405 & 0 & 196 & - & 226 & 514 & 239 & 55.9 \\
\hline
\end{tabular}

(1) Soils no. 1-20, data from Rein (2008); (2) Soils no. 21-23, data from Reatto et al. (2008); letters A and B, mean horizons A and B of soils; ${ }^{(3)} \mathrm{HF}$-microwave, chemical allocation method (Resende et al., 1987); Kt: kaolinite; Gb: gibbsite; Gt: goethite; Hm: hematite; An: anatase; ${ }^{(4)} \mathrm{H}_{2} \mathrm{SO}_{4} / \mathrm{NaOH}$ method (Camargo et al., 1986); T: cation exchange capacity at $\mathrm{pH} 7$.

Optimal best-fit values for the surface site acidity constants, $\log K_{a 1}^{\text {int }}$ and $\log K_{a 2}^{\text {int }}$, as well as surface site density for Oxisols from the Brazilian Cerrado, were calculated from a previous study (Table 1). These constants were fixed when the metal binding constants were calculated from the batch adsorption data.

The Davies equation (Davies, 1938)and a revision of the dissociation constants of some sulphates Journal of the Chemical Society (Resumed and the specific interaction theory (Sukhno and Buzko, 2004), both used for activity correction in Visual MINTEQ, were applied to adjust activity coefficients in extrapolation of equilibrium constants in $I=0.1 \mathrm{~mol} \mathrm{~L}^{-1}$ (Table 3). Equilibrium constants of dissolved species extrapolated to $I=0.1 \mathrm{~mol} \mathrm{~L}^{-1}$ by the Davies equation (Equation 7) were used to optimize $\log K_{\text {SOCd }}^{\text {int }}$ by FITEQL 4.0 (Herbelin and Westall, 1999), and were used in further modeling through Visual MINTEQ. There is no generally accepted convention for treating activity coefficients of surface species (Richter et al., 2005). In general, there is little or no change in the $\mathrm{pH}$ dependence of adsorption with ionic strength (between 0.001-1.0 $\mathrm{mol} \mathrm{L}^{-1}$ ) for specifically adsorbed ions like $\mathrm{Cu}^{2+}, \mathrm{Pb}^{2+}, \mathrm{Ni}^{2+}$, and $\mathrm{Cd}^{2+}$ (Hayes and Leckie, 1987); therefore, adopted protonation/dissociation constants were obtained from a previous study in $0.1 \mathrm{~mol} \mathrm{~L}^{-1} \mathrm{NaCl}$. The Davies equation is:

$-\log \gamma_{i}=0.5 z_{i}^{2}\left(\frac{\sqrt{ } I}{1+\sqrt{ } I}-0.3 I\right)$ Eq. 7

where the subscript $i$ refers to each of the reactants and products in the reaction; $z_{i}$ is the ionic charge of each reactant or product; and $I$ is the ionic strength reported for the experimental data.

Once computed, the activity coefficients were used in the following relationship to correct the equilibrium constants to $\mathrm{I}=0.1 \mathrm{~mol} \mathrm{~L}^{-1}$ : 
Table 2. Soil texture, organic matter content and surface area

\begin{tabular}{|c|c|c|c|c|}
\hline Soil & Clay & Sand & $\mathrm{OC}^{(3)}$ & $A^{(4)}$ \\
\hline & & $\mathrm{g} \mathrm{kg}^{-1}$ & & $\mathrm{~m}^{2} \mathrm{~g}^{-1}$ \\
\hline 1 & 836 & 95 & 32.1 & 81 \\
\hline 2 & 877 & 28 & 31.3 & 86 \\
\hline 3 & 209 & 719 & 9.9 & 33 \\
\hline 4 & 700 & 106 & 26.9 & 148 \\
\hline 5 & 182 & 767 & 5.2 & 11 \\
\hline 6 & 396 & 550 & 17.4 & 43 \\
\hline 7 & 137 & 841 & 5.6 & 11 \\
\hline 8 & 363 & 611 & 11.8 & 35 \\
\hline 9 & 841 & 115 & 24.4 & 88 \\
\hline 10 & 672 & 263 & 21.3 & 84 \\
\hline 11 & 176 & 759 & 11.6 & 25 \\
\hline 12 & 454 & 466 & 22.3 & 81 \\
\hline 13 & 521 & 403 & 23.2 & 80 \\
\hline 14 & 169 & 811 & 10.6 & 14 \\
\hline 15 & 368 & 574 & 12.4 & 34 \\
\hline 16 & 268 & 672 & 7.2 & 20 \\
\hline 17 & 138 & 712 & 14.5 & 28 \\
\hline 18 & 695 & 53 & 36.6 & 133 \\
\hline 19 & 433 & 519 & 20.7 & 48 \\
\hline 20 & 814 & 158 & 27.1 & 65 \\
\hline $21 \mathrm{~A}^{(2)}$ & 600 & 230 & 26.5 & 51 \\
\hline $21 \mathrm{~B}$ & 750 & 160 & 0.2 & 65 \\
\hline $22 \mathrm{~A}$ & 670 & 220 & 20.1 & 56 \\
\hline $22 \mathrm{~B}$ & 700 & 160 & 5.9 & 65 \\
\hline $23 \mathrm{~A}$ & 670 & 230 & 0.7 & 86 \\
\hline $23 \mathrm{~B}$ & 750 & 180 & 0.2 & 96 \\
\hline
\end{tabular}

(1) Soils no. 1-20, data from Rein (2008); ${ }^{(2)}$ Soils no. 21-23, data from Reatto et al. (2008); letters A and B, mean horizons A and B of soils; ${ }^{(3)}$ Organic carbon (Embrapa, 1979); (4) A: specific surface area obtained in the present study.

$$
K_{I=0}=K_{I^{\prime}}\left(\frac{\prod_{i} \gamma_{i, \text { products }}^{v}}{\prod_{i} \gamma_{i, \text { reactants }}^{v}}\right)
$$

where $v$ represents the reactant or product stoichiometric coefficient.

The dominant $\mathrm{Cd}$ solution species in groundwater at $\mathrm{pH}$ values greater than 8.2 is $\mathrm{CdCO}_{3}(\mathrm{aq})$. Precipitation with carbonate is increasingly important in systems with a $\mathrm{pH}$ greater than 8 (USEPA, 1999). However, Brazilian Oxisols are rather acidic soils; therefore, the effect of partial $\mathrm{CO}_{2}$ pressure, and its related compounds, in simulated suspensions was not included in Visual MINTEQ or FITEQL calculations.

The FITEQL program was used to optimize surface complexation modeling of the experimental $\mathrm{Cd}$ adsorption. The program was set to allow ionic strength and activity corrections. FITEQL uses the Davies equation to correct ionic activity (Equation 7). Obtained equilibrium constants were averaged using the weighting method of Dzombak and Morel (1990), in which the weighting factor $w_{i}$ is defined as:

$w_{i}=\frac{\left(1 / \sigma_{\log K}\right)_{i}}{\sum\left(1 / \sigma_{\log K}\right)_{i}}$

where $\left(\sigma_{\log K}\right)$ i is the standard deviation of $\log \mathrm{K}$ calculated by FITEQL for the $i^{\text {th }}$ data set. The best estimate for $\log \mathrm{K}$ is then calculated as:

$\overline{\log K}=\sum w_{i}(\log K)_{i}$

Another method to optimize $\log K_{S o c d}^{\text {int }}$ values was employed. Using observed data as a guide parameter, simulations with Visual MINTEQ were used to optimize by trial and error (systematic variations of assumed values of $\log K_{S o c d}^{\text {int }}$ ) using the method of least squares regression (with a $\log K_{S O C d}^{\text {int }}$ precision of 0.01). This method seeks to minimize the sum of the squared errors (SSE) between observed and calculated values of the dependent variable, in this case the sorbed $\mathrm{Cd}$ concentration, S (Bolster and Hornberger, 2007):

$S S E=\sum_{i=1}^{N}[S i-S i]^{2}$

Eq. 11

where SSE is the objective function to be minimized; $N$ is the number of observations; $S i$ is the $i^{\text {th }}$ measured value of the dependent variable; and $S i$ is the $i^{\text {th }}$ model-predicted value of the dependent variable.

The constant capacitance model is very insensitive to values of capacity density $\left(\mathrm{C}_{1}\right)$ (Goldberg, 1995). The choice of the $\mathrm{C}_{1}$ value is arbitrary, and it is recommend to use the best fit values $\left(\sim 1.0 \mathrm{~F} \mathrm{~m}^{-2}\right)$ (Hayes et al., 1991). We chose to use the $\mathrm{C}_{1}$ value of $1.06 \mathrm{~F} \mathrm{~m}^{-2}$ (derived from $\mathrm{Al}$ oxides) (Westall and Hohl, 1980), which is usually used for soil modeling (Goldberg et al., 2000).

Intrinsic equilibrium constants passed through Dixon's outlier and normality (Shapiro-Wilk and Lilliefors) tests using PROUCL software (Maichle and Singh, 2013).

\section{Validation}

The validation of the surface complexation models obtained with adsorption of $\mathrm{Cd}$ in 16 soil samples collected by Rein (2008) and six by Reatto et al. (2008) was carried out using four soil samples from different localities (Sete Lagoas, São Gotardo, Uberaba, and Itumbiara), collected in a transect by Rein (2008). These four soil samples were not used during model prediction. The set up for the validation experiments was the same as that used for prediction. All model parameters have been maintained unvaried; therefore, the results presented are a test of the ability of the model to simulate $\mathrm{Cd}$ adsorption in these four soils. 
Table 3. Proton and metal binding parameters used in the model for metal adsorption ${ }^{(1)}$ onto Oxisols from the Brazilian Cerrado

\begin{tabular}{|c|c|c|c|}
\hline Surface acidity constant ${ }^{(2)}$ & \multicolumn{3}{|c|}{ Input parameter } \\
\hline Diffuse layer model & \multirow{2}{*}{\multicolumn{3}{|c|}{ Site concentration $\left(\mathrm{mmol} \mathrm{kg}^{-1}\right)=109.9$}} \\
\hline $\begin{array}{l}\log K_{a 1}^{i n t}=2.93 \\
\log K_{a 2}^{i n t}=-5.92\end{array}$ & & & \\
\hline Constant capacitance model & \multirow{3}{*}{\multicolumn{3}{|c|}{$\begin{array}{l}\text { Site concentration }\left(\mathrm{mmol} \mathrm{kg}^{-1}\right)=113.7 \\
\text { Capacitance }\left(\mathrm{F} \mathrm{m}^{-2}\right)=1.06\end{array}$}} \\
\hline $\begin{array}{l}\log K_{a 1}^{i n t}=3.51 \\
\log K_{a 2}^{i n t}=-5.94\end{array}$ & & & \\
\hline Common input parameter ${ }^{(3)}$ & & & \\
\hline \multirow{2}{*}{ Reaction } & \multicolumn{3}{|c|}{$\log \mathrm{K}$} \\
\hline & $\mathrm{I}^{(4)}=0$ & $I=0.1$ (Davies) $^{(5)}$ & $I=0.1(\mathrm{SIT})^{(6)}$ \\
\hline$C d^{2+}+C l^{-}=C d C l_{(a q)}^{+}$ & 1.980 & 2.410 & 2.397 \\
\hline$C d^{2+}+2 C l^{-}=C d C l_{2(a q)}$ & 2.600 & 3.244 & 3.206 \\
\hline $\mathrm{Cd}^{2+}+\mathrm{OH}^{-}=\mathrm{CdOH}_{(a q)}^{+}$ & -10.097 & -9.667 & -9.691 \\
\hline $\mathrm{Cd}^{2+}+\mathrm{OH}^{-}=\mathrm{CdOH}_{(a q)}^{3+}$ & -9.397 & -9.397 & -9.440 \\
\hline $\mathrm{Cd}^{2+}+2 \mathrm{OH}=\mathrm{Cd}(\mathrm{OH})_{2(a q)}$ & -20.294 & -19.650 & -19.690 \\
\hline $\mathrm{Cd}^{2+}+3 \mathrm{OH}^{-}=\mathrm{Cd}_{2}(\mathrm{OH})_{3(a q)}^{+}$ & -33.3 & -32.656 & -32.702 \\
\hline $\mathrm{Na}^{+}+\mathrm{OH}^{-}=\mathrm{NaOH}_{(a q)}$ & -13.897 & -13.682 & -13.687 \\
\hline $\mathrm{Na}^{+}+\mathrm{Cl}^{-}=\mathrm{NaCl}_{(a q)}$ & -0.300 & -0.085 & -0.089 \\
\hline$H_{2} 0+H_{2} 0=H_{3} 0+\mathrm{OH}^{-}$ & -13.997 & -13.782 & -13.796 \\
\hline
\end{tabular}

(1) Suspension concentration $=50 \mathrm{~g} \mathrm{~L}^{-1}$; site concentration $\left(\mathrm{Nt} ; \mathrm{mol} \mathrm{kg}^{-1}\right)$ may be converted to site density $\left(\mathrm{Ns}\right.$; sites nm $\left.{ }^{-2}\right)$ by the following expression: $\mathrm{Nt}=\left(\mathrm{SA} \times \mathrm{Ns} \times \mathrm{CS} \times 10^{18}\right) / \mathrm{NA}$, where SA is the surface area $\left(\mathrm{m}^{2} \mathrm{~g}^{-1}\right)$; CS is $\mathrm{g}$ of soil L $\mathrm{L}^{-1}$; and NA is Avogadro's number; (2) $298.15 \mathrm{~K}$; ${ }^{(3)}$ Data from Martell and Smith (2003); ${ }^{(4)}$ I: ionic strength in mol L-1; ${ }^{-15}$ Davies (1938); ${ }^{(6)}$ Sukhno and Buzko (2004).

Observed vs. predicted plots of Cd adsorption values from this series of soils were compared using the root mean square error (RMSE) and a dimensionless statistic which directly relates model predictions to observed data such as modeling efficiency (EF) (Mayer and Butler, 1993):

$R M S E=\left\{\frac{\sum_{i=1}^{N}\left(\hat{y}_{i}-y_{i}\right)^{2}}{n}\right\}^{0.5}$

where $y_{i}$ represents observed values; $\hat{y}_{i}$, simulated values; and $n$, the number of pairs.

$E F=1-\frac{\sum_{i=1}^{N}\left(\hat{y}_{i}-y_{i}\right)^{2}}{\sum_{i=1}^{N}\left(\hat{y}_{i}-\bar{y}\right)^{2}}$

where $\bar{y}$ represents the observed mean.

\section{RESULTS AND DISCUSSION}

\section{Isotherms and constants}

Measured surface areas (average \pm standard deviation, $\mathrm{n}=20)$ from kaolinite $(\mathrm{KGa}-2)$ and a Ca-Montmorilonite (SAz-1) were $44.75 \pm 8.16$ and $806.03 \pm 53.11 \mathrm{~m}^{2} \mathrm{~g}^{-1}$, respectively. The values are close to the theoretical values for the clay minerals, and to reported values (van Olphen and Fripiat, 1979; Cerato and Lutenegger, 2002; Kennedy and Wagner, 2011).
Intrinsic equilibrium constants estimated by FITEQL were 0.29 and 0.38 units smaller for DLM and CCM, respectively, than those calculated by hand (Table 4). Confidence intervals were also narrower for the hand calculation group than those calculated by FITEQL. Very similar statistical results (standard deviation and confidence intervals) were found for DLM and CCM. Intrinsic equilibrium constants optimized by FITEQL and hand calculation differed significantly (Table 4).

A possible explanation for the difference between $\log K_{\text {SOCd }}^{\text {int }}$ results from FITEQL and from hand calculation using Visual MINTEQ may be related to FITEQL numerical instability or convergence problems (Villegas-Jiménez and Mucci, 2009). Speciation constants for major reactions used in FITEQL exactly matched those in Visual MINTEQ (Table 3). Output data from FITEQL, however, was able to predict the observed data with precision (Figure 1), and preliminary tests optimizing constants without taking into account background ionic strength $\left(0.1 \mathrm{~mol} \mathrm{~L}{ }^{-1} \mathrm{NaCl}\right.$; in both software programs, FITEQL and Visual MINTEQ) were satisfactory, and predicted the observed results perfectly, but they did not correspond to reality. When optimized intrinsic equilibrium constants estimated by FITEQL were added to the Visual MINTEQ database including background ionic strength data, the program failed to accurately predict observed results of $\mathrm{Cd}$ adsorption (Figures 2 and 3). Some authors use site density to ultimately optimize curve fitting (Davis and 
Kent, 1990) because as site density increases, the adsorption edge shifts to lower $\mathrm{pH}$ values, whereas with decreasing site density, the adsorption edge shifts to higher $\mathrm{pH}$ values, allowing the modelist to adjust curve fitting "manually". Using changes in site density to adjust curve fitting was not our intent in the present study. Rather, we searched for a hand calculation method that could provide more accurate results when using Visual MINTEQ, and that could be used as a reference, since as it was optimized accessing by Visual MINTEQ data directly (Table 4).

Intrinsic equilibrium constants optimized by hand calculation, considering a $0.1 \mathrm{~mol} \mathrm{~L}^{-1} \mathrm{NaCl}$ background, was incorporated in the Visual MINTEQ database. The results showed good precision in reproducing the observed values (Figures 2 and 3). Using this approach, the diffuse layer and constant capacitance models produced very similar results. In fact, differences between models are insignificant (Davis and Kent, 1990) when models have matching $\mathrm{pH}$ and ionic strength. A sample from an Oxisol from Buritis, MG, based on estimated parameters from hand calculation, exhibited values of 0.14 and 0.15 for RSME for $\mathrm{Cd}$ adsorption, and 0.97 and 0.96 for $\mathrm{EF}$ in regard to DLM and CCM, respectively, showing very similar prediction values between models (Figures 2 and 3). When parameters estimated from FITEQL were added to Visual MINTEQ, RSME was high, and $\mathrm{EF}$ was low for both DLM and CCM (Figures 2 and 3). The latter statistical results clearly show disagreement among FITEQL optimization of $\log K_{\text {SOCd }}^{\text {int }}$ added into Visual MINTEQ and observed data (Figures 2 and 3).

\section{Validation}

Cadmium adsorption in four Oxisol samples collected in Sete Lagoas, MG; São Gotardo, MG;
Uberaba, MG; and Itumbiara, GO, was modeled using parameters estimated by hand calculation in Visual MINTEQ (Table 4, Figure 4). Parameters derived from adsorption obtained at several fixed $\mathrm{pH}$ values were incorporated in the DLM to reproduce $\mathrm{pH}$ edge curves. Only DLM using optimization by hand calculation was shown in figure 4 since DLM and CCM showed equivalent results (Figure 1). Another reason for showing only DLM using optimization by hand calculation in figure 4 was that FITEQL optimized $\log K_{\text {SOCd }}^{\text {int }}$ values incorporated in Visual MINTEQ

Table 4. Average intrinsic equilibrium constants for $\mathrm{Cd}$ adsorption onto 20 Oxisols from the Brazilian Cerrado using the diffuse layer model (DLM) and the constant capacitance model (CCM), estimated by FITEQL 4.0 and by hand calculation using Visual MINTEQ ${ }^{(1)}$

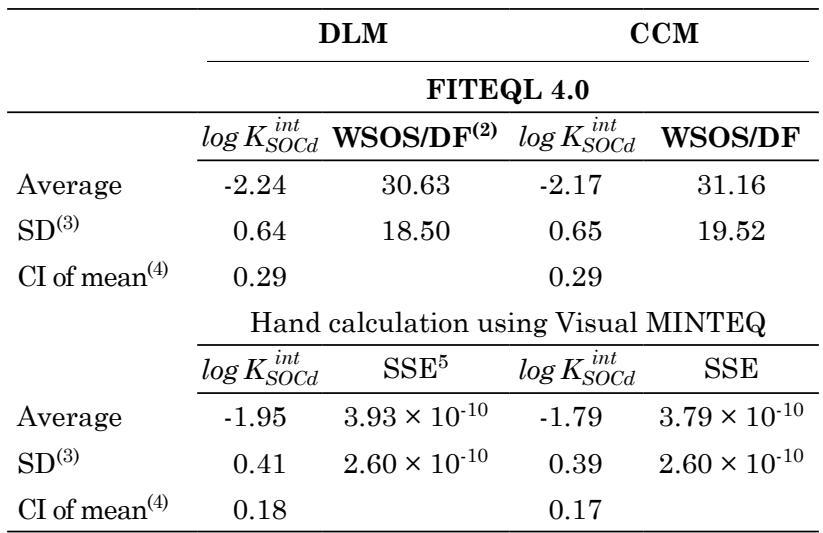

(1) Suspension concentration $=50 \mathrm{~g} \mathrm{~L}^{-1}$; Capacitance of inner Helmholtz layer $=1.06 \mathrm{~F} \mathrm{~m}^{-2}$; Site density $=0.4295$ and 0.4444 sites $\mathrm{nm}^{-2}$ for DLM and CCM, respectively; ${ }^{(2)}$ WSOS is the weighted sum of squares of the residuals and DF is the degrees of freedom; ${ }^{(3)} \mathrm{SD}$ : standard deviation from $\log \mathrm{K}$ values; ${ }^{(4)} \mathrm{CI}$ of mean $=95 \%$ confidence interval; ${ }^{(5)} \mathrm{SSE}$ : sum of the squared errors.
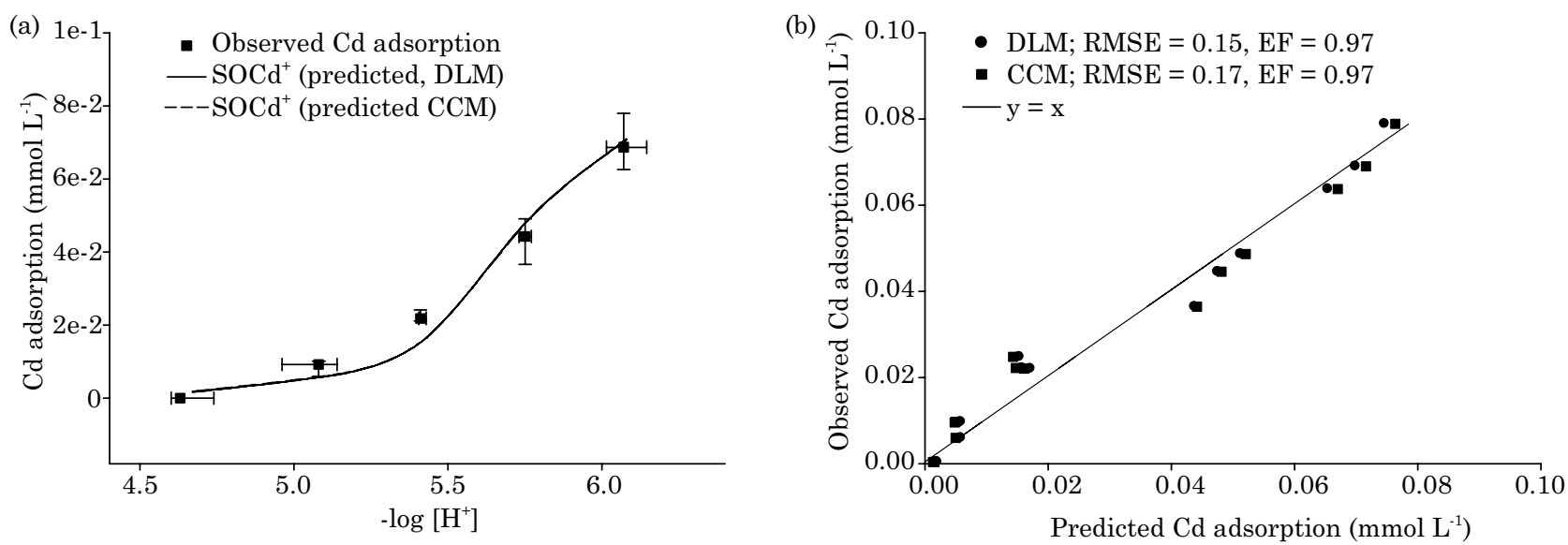

Figure 1. Cadmium adsorption as a function of pH in an Oxisol from Buritis, MG, Brazil, using observed and FITEQL output data: DLM = diffuse layer model and CCM = constant capacitance model (Capacitance of inner Helmholtz layer $=1.06 \mathrm{~F} \mathrm{~m}^{-2}$ ); Suspension concentration $=50 \mathrm{~g} \mathrm{~L}^{-1}$; surface area $=35.22 \mathrm{~m}^{2} \mathrm{~g}^{-1} ; 0.1 \mathrm{~mol} \mathrm{~L}^{-1} \mathrm{NaCl} ; \mathrm{RMSE}=$ root mean square error; $\mathrm{EF}=$ model efficiency. 
resulted in high RMSE and low EF values (Figures 2 and 3), contrasting with low RMSE and high EF obtained using hand calculation optimized $\log K_{\text {SOCd }}^{\text {int }}$ values incorporated in Visual MINTEQ. Confidence limits were calculated from $\log K_{S O C d}^{\text {int }}$ dispersion (obtained from optimization of $\mathrm{Cd}$ adsorption in those 22 soil samples by hand calculation for the DLM) plotted against $\mathrm{pH}$ (Figure 4). Although it is interesting to know the likely range of a true value using $\log K_{S O C d}^{i n t}$, it is important to show that each value of $\log K_{S O C d}^{\text {int }}$ is related to its soil surface area. Therefore, the confidence interval established using only one value of soil surface area (from the sample under analysis) shows narrowed confidence intervals. Taking soil surface area into account, calculated confidence limits would probably show larger intervals. Therefore, another model of goodness of fit statistics was assessed, for purposes of validation, using RMSE and EF (Equations 12 and 13). In the end, cadmium adsorption was modeled satisfactorily in all four soils, according to validation statistics (Figure 5).
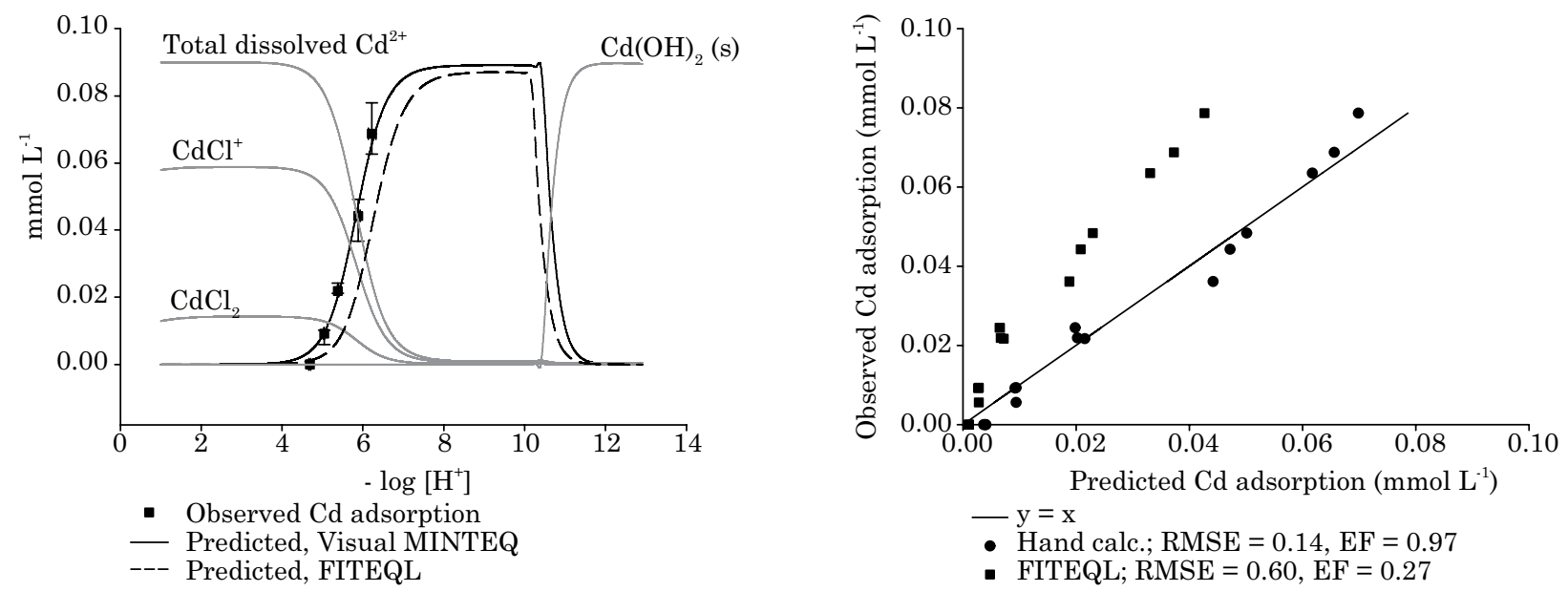

Figure 2. Cadmium adsorption as a function of pH in an Oxisol from Buritis, MG. The diffuse layer model was used in Visual MINTEQ multiple (sweep mode) speciation to draw lines on the graph, using intrinsic equilibrium constants optimized by FITEQL $\left(\log K_{S O C d}^{\text {int }}=\mathbf{- 2 . 5 0}\right)$ as well as by hand calculation using Visual MINTEQ $\left(\log K_{S O C d}^{i n t}=-1.99\right)$; suspension concentration $=50 \mathrm{~g} \mathrm{~L}^{-1}$; surface area $=35.22 \mathrm{~m}^{2} \mathrm{~g}^{-1}$; $0.1 \mathrm{~mol} \mathrm{~L}^{-1} \mathrm{NaCl} ; \mathrm{RMSE}=$ root mean square error; $\mathrm{EF}=$ model efficiency.
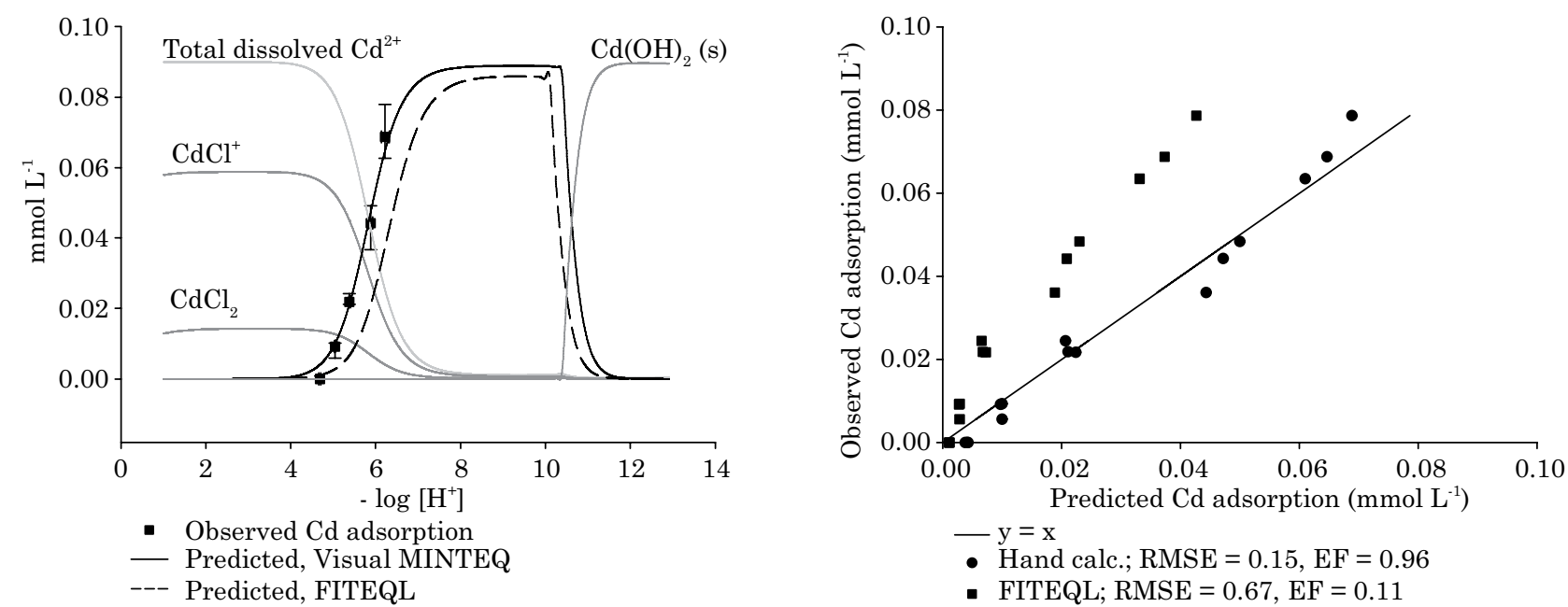

Figure 3. Cadmium adsorption as a function of $\mathrm{pH}$ in an Oxisol from Buritis, MG. The constant capacitance model was used in Visual MINTEQ multiple (sweep mode) speciation to draw lines on the graph, using intrinsic equilibrium constants optimized by FITEQL $\left(\log K_{S O C d}^{i n t}=-2.53\right)$ as well as by hand calculation using Visual MINTEQ $\left(\log K_{S O C d}^{\text {int }}=-1.91\right)$; capacitance of inner Helmholtz layer $=1.06 \mathrm{~F} \mathrm{~m}^{-2}$; suspension concentration $=50 \mathrm{~g} \mathrm{~L}^{-1}$; surface area $=35.22 \mathrm{~m}^{2} \mathrm{~g}^{-1} ; 0.1 \mathrm{~mol} \mathrm{~L}^{-1} \mathrm{NaCl}$; $\mathrm{RMSE}=$ root mean square error; $\mathrm{EF}=$ model efficiency . 


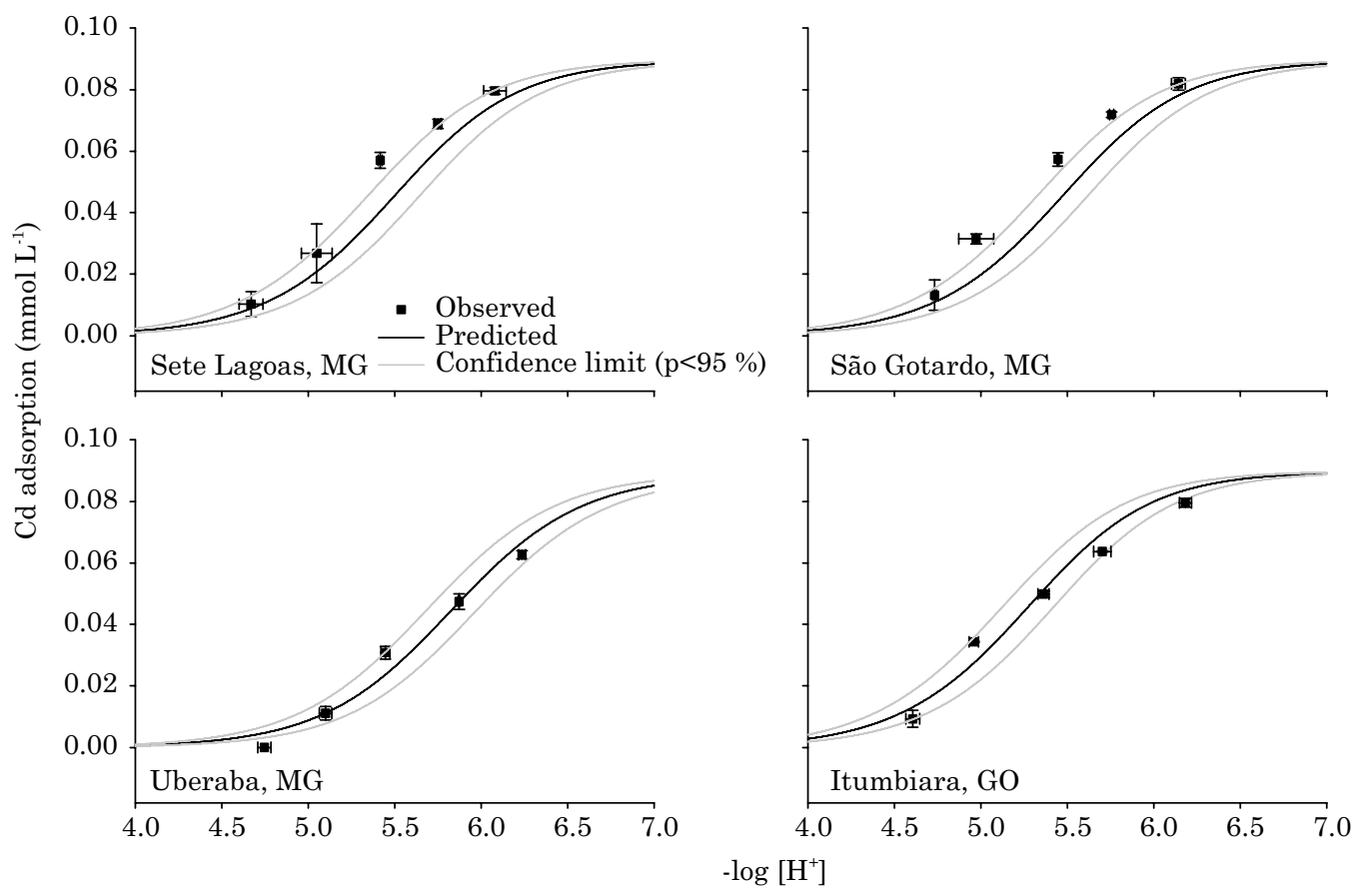

Figure 4. Cadmium adsorption as a function of pH in four Oxisols from Sete Lagoas, MG; São Gotardo, MG; Uberaba, MG; and Itumbiara, GO (soils no. 1-4, table 1) used for model validation. The diffuse layer model was used in Visual MINTEQ multiple (sweep mode) speciation to draw lines on the graph. Intrinsic equilibrium constants optimized by hand calculation using Visual MINTEQ were used as input values in Visual MINTEQ; suspension concentration $=50 \mathrm{~g} \mathrm{~L}^{-1} ; 0.1 \mathrm{~mol} \mathrm{~L}^{-1} \mathrm{NaCl}$; $\log K_{S O C d}^{\text {int }}=-1.95$.
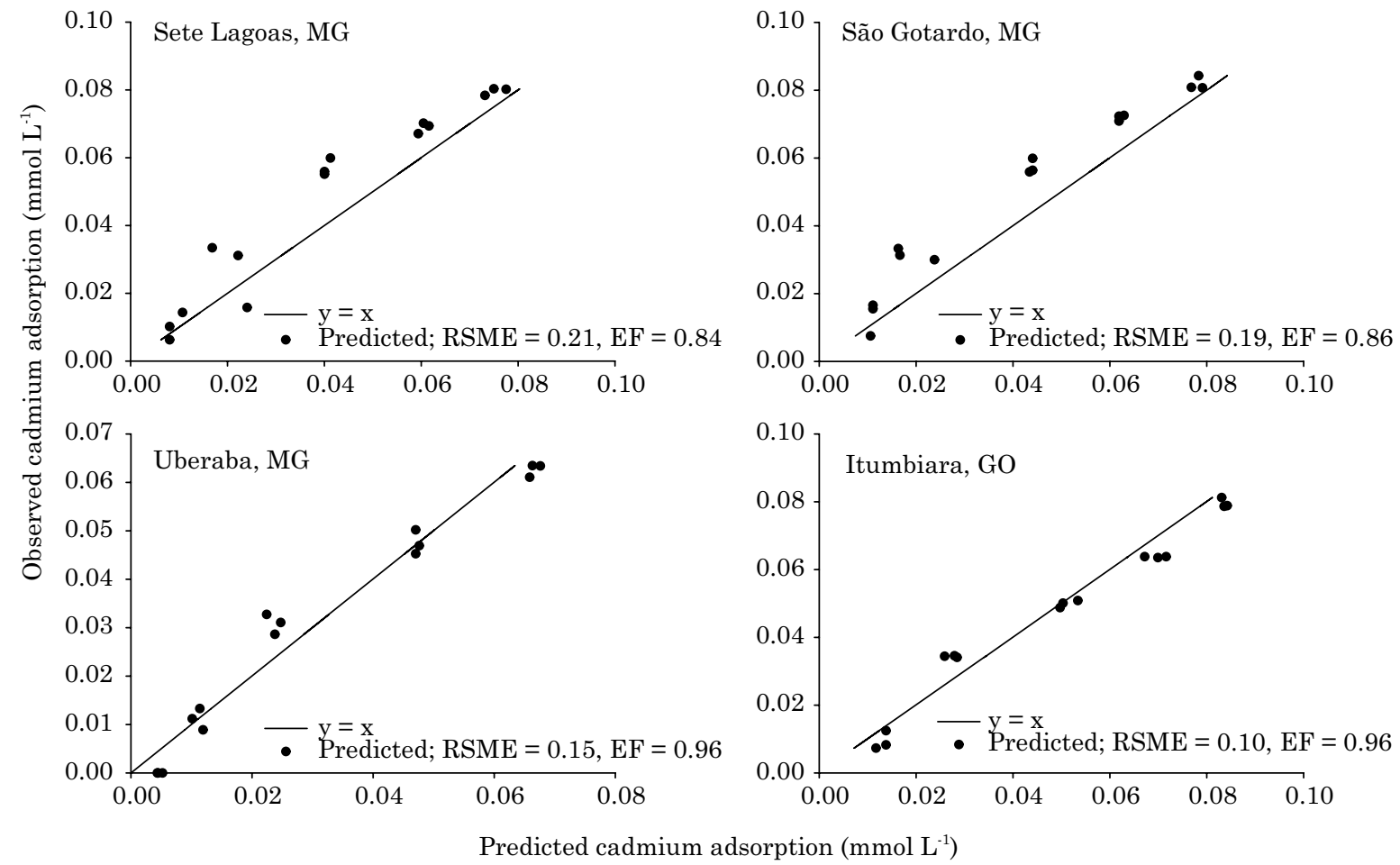

Figure 5. Observed vs. predicted cadmium adsorption as a function of $\mathrm{pH}$ in four Oxisols from Sete Lagoas, MG; São Gotardo, MG; Uberaba, MG; and Itumbiara, GO. Intrinsic equilibrium constants optimized by hand calculation using Visual MINTEQ were used as input values in Visual MINTEQ for Cd prediction using the diffuse layer model; suspension concentration $=50 \mathrm{~g} \mathrm{~L}^{-1} ; 0.1 \mathrm{~mol} \mathrm{~L}^{-1} \mathrm{NaCl} ; \log K_{\text {SOCd }}^{i n t}=-1.95$. 


\section{CONCLUSIONS}

Values of $\log K_{\text {SOCd }}^{\text {int }}$, as well as all other parameters involved, such as surface acidity constants and site concentration, are ready to be incorporated in chemical equilibrium software.

Diffuse layer and constant capacitance model parameters, when incorporated in chemical equilibrium software, allow prediction of $\mathrm{Cd}$ adsorption in Oxisols with high efficiency and accuracy.

Although FITEQL output rendered significant predicted vs. observed values of $\mathrm{Cd}$ adsorption, when the optimized $\log K_{S O C d}^{\text {int }}$ was incorporated into Visual MINTEQ, predicted Cd adsorption vs. observed values rendered high RSME and low EF, showing discrepancies between programs.

With the use of $\log K_{S O C d}^{\text {int }}$ estimated by hand calculation, predicted $\mathrm{Cd}$ adsorption vs. observed values rendered lower RSME and higher EF than the $\log K_{S O C d}^{\text {int }}$ estimated by FITEQL (when running these constants under Visual MINTEQ).

\section{ACKNOWLEDGMENTS}

The authors wish to thank Dr. Sabine Goldberg from the University of Riverside, Riverside, CA, USA, and Dr. Mariana Gabos Mendes from Embrapa Cerrados, Planaltina, DF, Brazil, for helpful comments during the proposal and calculation phases of this study; Dr. Willie Harris, from the University of Florida, Gainesville, FL, USA, for his critical remarks regarding determination of specific surface area of soils.

\section{REFERENCES}

Alleoni LRF, Camargo OAD. Modelos de dupla camada difusa de Gouy-Chapman e Stern aplicados a Latossolos ácricos paulistas. Sci Agric. 1994;51:315-20.

Appel C, Ma L. Concentration, $\mathrm{pH}$, and surface charge effects on cadmium and lead sorption in three tropical soils. J Environ Qual. 2002;31:581-9.

Agency for Toxic Substances and Disease Registry - ATSDR. Toxicological profile for cadmium. Atlanta [Georgia]: 2012.

Bethke CM. Geochemical and biogeochemical reaction modeling. New York: Cambridge University Press; 2008.

Bolster CH, Hornberger GM. On the use of linearized Langmuir equations. Soil Sci Soc Am J. 2007;71:1796-806.

Camargo OA, Moniz AC, Jorge JA, Valadares JMAS. Métodos de análise química, mineralógica e física de solos do Instituto Agronômico de Campinas. Campinas: Instituto Agronômico de Campinas; 1986.

Cerato AB, Lutenegger AJ. Determination of surface area of fine-grained soils by the ethylene glycol monoethyl ether (EGME) method. Geotech Test J. 2002;25:315-21.
Charlet L, Sposito G. Monovalent ion adsorption by an Oxisol. Soil Sci Soc Am J. 1987;51:1155-60.

Davies CW. The extent of dissociation of salts in water. Part VIII. An equation for the mean ionic activity coefficient of an electrolyte in water, and a revision of the dissociation constants of some sulphates. J Chem Soc. 1938;1:2093-8.

Davis JA. Surface complexation modeling of uranium (VI) adsorption on natural mineral assemblages. Menlo Park [CA]: U.S. Geology Survey; 2001.

Davis JA, Kent DB. Surface complexation modeling in aqueous geochemistry. In: Hochella, MF, White AF, editors. Mineral water interface geochemistry. Menlo Park [CA]: Mineralogical Society of America; 1990. p.177-260.

Dzombak DA, Morel FMM. Surface complexation modeling: hydrous ferric oxide. New York: John Wiley; 1990.

Empresa Brasileira de Pesquisa Agropecuária - Embrapa. Serviço Nacional de Levantamento e Conservação de Solos. Manual de métodos de solo. Rio de Janeiro: 1979.

Goldberg S. Adsorption models incorporated into chemical equilibrium models. Chemical equilibrium and reaction models. Madison [WI]: Soil Science Society of America; 1995. p.75-95.

Goldberg S. Use of surface complexation models in soil chemical-systems. Adv Agron. 1992;47:233-329.

Goldberg S, Lesch SM, Suarez DL. Predicting boron adsorption by soils using soil chemical parameters in the constant capacitance model. Soil Sci Soc Am J. 2000;64:1356-63.

Guilherme LRG, Marchi G, Gonçalves VC, Pinho PJ, Pierangeli MAP, Rein TA. Metais em fertilizantes inorgânicos: avaliação de risco à saúde após a aplicação. $2^{\mathrm{a}}$.ed. Lavras: Universidade Federal de Lavras; 2014.

Gustafsson JP. Visual Minteq, 3.1. Stockholm: KTH, Deptartment of Land and Water Resources Engineering; 2014.

Hayes KF, Leckie JO. Modeling ionic-strength effects on cation adsorption at hydrous oxide-solution interfaces. J Colloid Interf Sci. 1987;115:564-72.

Hayes KF, Redden G, Ela W, Leckie JO. Surface complexation models - an evaluation of model parameter-estimation using FITEQL and oxide mineral titration data. J Colloid Interf Sci. 1991;142:448-69.

He ZL, Xu HP, Zhu YM, Yang XE, Chen GC. Adsorption-desorption characteristics of cadmium in variable charge soils. J Environ Sci Health A Tox Hazard Subst Environ Eng. 2005;40:805-22.

Herbelin A, Westall J. FITEQL 4.0: a computer program for determination of chemical equilibrium constants from experimental data. Corvalis [Oregon]: Department of Chemistry, Oregon State Univeristy; 1999.

Hooda PS. Trace elements in soils. Chichester [United Kingdom]: Blackwell Publishing; 2010.

Kennedy MJ, Wagner T. Clay mineral continental amplifier for marine carbon sequestration in a greenhouse ocean. Proc Nat Acad Sci USA. 2011;108:9776-81.

Koretsky C. The significance of surface complexation reactions in hydrologic systems: a geochemist's perspective. J Hydrol. 2000;230:127-71.

Lee SZ, Allen HE, Huang CP, Sparks DL, Sanders PF, Peijnenburg WJGM. Predicting soil-water partition coefficients for cadmium. Environ Sci Technol. 1996;30:3418-24. 
Maichle R, Singh A. PRO-UCL 5.0. Statistical software for environmental applications for data sets with and without nondetect observations. Atlanta [GA]: USEPA; 2013.

Martell AE, Smith RM. NIST Standard Reference Database, 46.7. Gaithersburg: National Institute of Standards and Technology; 2003.

Mayer DG, Butler DG. Statistical validation. Ecol Model. 1993;68:21-32.

Pierangeli MAP, Oliveira LR, Curi N, Guilherme LRG, Silva MLN. Efeito da força iônica da solução de equilíbrio na adsorção de cádmio em Latossolos brasileiros. Pesq Agropec Bras. 2003;38:737-45.

Reatto A, Bruand A, Martins ED, Muller F, Silva EM, Carvalho OA, Brossard M. Variation of the kaolinite and gibbsite content at regional and local scale in Latosols of the Brazilian Central Plateau. Comp Rendus Geosci. 2008;340:741-8.

Reatto A, Bruand A, Martins ED, Muller F, Silva EM, Carvalho OA, Brossard M, Richard G. Development and origin of the microgranular structure in Latosols of the Brazilian Central Plateau: significance of texture, mineralogy, and biological activity. Catena. 2009a;76:122-34.

Reatto A, Bruand A, Silva EM, Guegan R, Cousin I, Brossard M, Martins ES. Shrinkage of microaggregates in Brazilian Latosols during drying: significance of the clay content, mineralogy and hydric stress history. Eur J Soil Sci. 2009b;60:1106-16.

Reatto A, Bruand A, Silva EM, Martins ES, Brossard M. Hydraulic properties of the diagnostic horizon of Latosols of a regional toposequence across the Brazilian Central Plateau. Geoderma. 2007;139:51-9.

Rein TA. Surface chemical properties and nitrate adsorption of Oxisols from the Brazilian Savannas [thesis]. Ithaca: Cornell University; 2008.
Resende M, Bahia Filho AFC, Braga JM. Mineralogia da argila de Latossolos estimada por alocação a partir do teor total de óxidos do ataque sulfúrico. R Bras Ci Solo. 1987;11:17-23.

Richter A, Brendler V, Nebelung C. Blind prediction of $\mathrm{Cu}(\mathrm{II})$ sorption onto goethite: current capabilities of diffuse double layer model. Geochim Cosmochim Acta. 2005;69:2725-34.

Sauvé S, Hendershot W, Allen HE. Solid-solution partitioning of metals in contaminated soils: Dependence on $\mathrm{pH}$ total metal burden, and organic matter. Environ Sci Technol. 2000;34:1125-31.

Shi Z, Allen HE, Di Toro DM, Lee SZ, Flores Meza DM, Lofts S. Predicting cadmium adsorption on soils using WHAM VI. Chemosphere. 2007;69:605-12.

Sukhno I, Buzko V. Ionic strength correction for stability constants using specific interaction theory (SIT). Krasnodar [Russia]: IUPAC; Kuban State University, 2004.

United States Environmental Protection Agency - USEPA. Understanding variation in partition coefficient, $\mathrm{kd}$, values. Volume II: review of geochemistry and available kd values for cadmium, cesium, chromium, lead, plutonium, radon, strontium, thorium, tritium $\left({ }^{3} \mathrm{H}\right)$, and uranium. Washington: Office of Air and Radiation; 1999.

van Olphen H, Fripiat JJ. Data handbook for clay minerals and other non-metallic minerals. Oxford: Pergamon Press; 1979.

Villegas-Jiménez A, Mucci A. Estimating intrinsic formation constants of mineral surface species using a genetic algorithm. Math Geosci. 2009;42:101-27.

Westall J, Hohl H. A comparison of electrostatic models for the oxide/solution interface. Adv. Colloid Interf Sci. 1980;12:265-94. 